\title{
IMPLEMENTASI TANGGUNG JAWAB PENGELOLA APOTIK TERHADAP KONSUMEN OBAT
}

\author{
Mig Irianto Legowo*
}

\begin{abstract}
The pharmacy is a pharmacy or place of service where pharmacy practice is carried out by pharmacists. In accordance with the provisions of a pharmacist can establish a Pharmacy with its own capital and / or capital from a capital owner both individuals and companies. Furthermore, in the case of pharmacists who establish a pharmacy in collaboration with capital owners, the work of organizing mandatory pharmacy is still carried out entirely by the pharmacist in question, therefore the responsibility of the pharmacist is as the manager of the pharmacy, which raises responsibility for the drug consumers The businessman/manager of the pharmacy is also obliged to provide the right service and information to the drug consumers. This study entitled Implementation of the Responsibility of Pharmacy Management for Drug Consumers aims to (1) know the responsibility of the pharmacist / manager to consumers in providing medicines, (2) to find out the problems faced by businessmen I managers of pharmacies in carrying out their obligations to dru. The type of research used is normative juridical with research specifications that are descriptive analytical. In this study the data is obtained from secondary data as primary data and primary data as supporting data (complementary). While the data collection method is interviews for primary data and literature studies for secondary data. The data obtained is presented in the form of a description of the event and then analyzed by qualitative descriptive analysis. In the case of a Pharmacy committing a serious violation that is life-threatening, then the SIA sanction for a Pharmacist's License Letter can be revoked without prior warning. (2) problems of problems faced by employers or managers of pharmacies include (a) drugs that are no longer circulating (b) drugs that have expired, (c) supplies of medicines run out. Then the business carried out by the pharmacy entrepreneur is (a) the pharmacy gives substitute drugs that have the same use. (B) if the drug has expired the pharmacy will exchange the drug to PBF. (C) if the drug supply runs out the pharmacy will advise consumers to search the drug runs out to another pharmacy.
\end{abstract}

Keywords: Pharmacies, pharmacy practice, Drug Consumers

\section{PENDAHULUAN}

Cita-cita bangsa Indonesia adalah mewujudkan masyarakat adil dan makmur materiil dan spiritual.Dalam rangka mencapai cita-cita bangsa tersebut diselenggarakan pembangunan nasional

* Mig Irianto Legowo adalah Pengajar di Fakultas Hukum UNTAG Semarang, Bidang Kajian Hukum Perdata Email : migirianto55@gmail. com disemua bidang kehidupan yang berkesinambungan yang merupakan suatu rangkaian pembangunan yang menyeluruh, terpadu dan terarah.

Pembangunan kesehatan sebagai salah satu upaya pembangunan nasional diarahkan guna tercapainya kesadaran, kemauan dan kemampuan untuk hidup sehat bagi setiap penduduk agar dapat mewujudkan derajad kesehatan yang 
optimal. Penyelenggaraan pembangunan kesehatan meliputi upaya kesehatan dari sumber dayanya, harus dilakukan secara terpadu dan berkesinambungan guna mencapai hasil yang optimal. Untuk mencapai maksud tersebut, peran serta masyarakat termasuk swasta perlu diarahkan.dan dikembangkan sehingga dapat melakukan fungsi dan tanggung jawab sosialnya sebagai mitra pemerintah.

Peran pemerintah lebih dititik beratkan pada pembinaan, pengaturan dan pengawasan untuk terciptanya pemerataan pelayanan kesehatan dan tercapainya kondisi yang serasi dan seimbang antara upaya kesehatan yang dilaksanakan oleh pemerintah dan masyarakat termasuk swasta.Kewajiban untuk melakukan pemerataan dan peningkatan pelayanan kesehatan bagi seluruh lapisan masyarakat, menjadi tanggung jawab Pemerintah. Misalnya balai-balai pengobatan dan lembaga-lembaga kesehatan lainnya serta tidak kalah pentingnya yaitu Apotek dalam pemenuhan dan penyaluran kebutuhan obat-obatan ke segenap masyarakat secara merata.

Dalam arah kebijakan pembangun an di bidang kesehatan ditujukan untuk meningkatkan dan memelihara mutu lembaga pelayanan kesehatan melalui pemberdayaan sumber daya manusia secara berkelanjutan dan sarana prasarana dalam bidang medis, termasuk ketersediaan obat yang dapat dijangkau oleh masyarakat.

Pengamanan sediaan farmasi dan alat kesehatan diselenggarakan untuk melindungi masyarakat dari bahaya yang disebabkan oleh penggunaan sediaan farmasi dan alat kesehatan yang tidak memenuhi persyaratan mutu dan atau keamanan dan atau kemanfaatan.

Untuk itu pembangunan di bidang obat ditetapkan kebijakan obat nasional yang merupakan penjabaran Sistem Kesehatan Nasional (SKN) sebagai pedoman petunjuk pelaksanaan bagi seluruh upaya dan kegiatan di bidang
obat.Sebagai salah satu bagian dari upaya kesehatan maka upaya di bidang obat merupakan tanggung jawab bersama antara Pemerintah masyarakat termasuk swasta.

Salah satu pengelola bidang obat adalah apotek, Apotek adalah sarana pelayanan kefarmasian tempat dilakukan praktek kefarmasian oleh Apoteker. Sesuai dengan ketentuan seorang apoteker dapat mendirikan Apotek dengan modal sendiri dan/atau modal dari pemilik modal baik perorangan maupun perusahaan. Selanjutnya dalam hal Apoteker yang mendirikan apotek bekerjasama dengan pemilik modal maka pekerjaan kefarmasian harus tetap dilakukan sepenuhnya oleh apoteker yang bersangkutan. Tenaga kesehatan dalam bidang kefarmasian adalah Apoteker. Dalam Peraturan Pemerintah Nomor 51 Tahun 2009 tentang Pekerjaan kefarmasian, pasal 21 ayat (2) dijelaskan bahwa yang boleh melayani pemberian obat berdasarkan resep adalah Apoteker oleh karena itu tanggung jawab apoteker adalah sebagai pengelola apotek, yang menimbulkan tanggung jawab kepada konsumen obat. Sebagai pengelola apoteker bertanggung jawab terhadap penyaluran obat kepada orang yang tidak berhak atau penyaluran yang menyimpang dari ketentuan yang berlaku. Hal tersebut diatur dalam :

\section{Bidang Hukum Perdata}

Pasal 1366 KUH Perdata, berbunyi Setiap orang bertanggung jawab tidak saja untuk kerugian yang disebabkan perbuatan nya, tetapi juga untuk kerugian yang disebabkan kelalaian atau kurang hati-hati.

Pasal 1367 KUH Perdata, berbunyi Seseorang tidak saja bertanggung jawab untuk kerugian yang disebabkan karena perbuatannya sendiri, tetapi juga kerugian yang disebabkan karena perbuatan orangorang yang menjadi tanggungannya, atau disebabkan karena perbuatannya, atau disebabkan oleh barang-barang yang 
berharga di bawah pengawasannya. Majikan-majikan dan mereka yang mengangkat orang lain untuk mewakili urusan mereka, dalah bertanggung jawab tentang kerugian yang diterbitkan oleh pelayan-pelayan atau bawahan-bawahan mereka di dalam melakukan pekerjaan untuk mana orang-orang ini dipakainya

\section{Bidang Hukum Administrasi}

Sesuai dengan ketentuan dalam Pasal 31(1) Pelanggaran terhadap ketentuan dalam Peraturan Menteri kesehatan republik Indonesia nomer 9 tahun 2017 Tentang Apotek dapat dikenai sanksi administratif. (2) Sanksi adminis tratif sebagaimana dimaksud pada ayat (1) dapat berupa : a.peringatan tertulis; b.penghentian sementara kegiatan; danc.pencabutan SIA.

\section{Pasal 32}

(1) Pencabutan SIA sebagaimana di maksud dalam Pasal 31ayat (2) huruf c dilakukan oleh pemerintah daerah kabupaten/kota berdasarkan: a.hasil pengawasan; dan/atau b.rekomendasi Kepala Balai POM.

(2) Pelaksanaan pencabutan SIA sebagai mana dimaksud pada ayat (1) dilakukan setelah dikeluarkan teguran tertulis berturut-turut sebanyak 3 (tiga) kali dengan tenggang waktu masing-masing 1 (satu) bulan dengan menggunakan Formulir 8 .

(3) Dalam hal Apotek melakukan pelanggaran berat yang membahaya kan jiwa, SIA dapat dicabut tanpa peringatan terlebih dahulu.

(4) Keputusan Pencabutan SIA oleh pemerintah daerah kabupaten/kota disampaikan langsung kepada Apoteker dengan tembusan kepada Direktur Jenderal, kepala dinas kesehatan provinsi, dan Kepala Badan dengan menggunakan Formulir 9 sebagaimana terlampir.
(5) Dalam hal SIA dicabut selain oleh dinas kesehatan kabupaten/kota, selain ditembuskan kepada sebagaimana dimaksud pada ayat (4), juga ditembuskan kepada dinas kabupaten/ kota.

Pengelola apotek juga berkewajiban untuk memberikan pelayanan dan informasi yang benar kepada konsumen sebagaimana terlah tercantum dalam Peraturan Menteri Kesehatan Nomor : 9 tahun 2017 Tentang apotek.

Pasal 20 Penyelenggaraan pelayan an kefarmasian di Apotek harus menjamin ketersediaan Sediaan Farmasi, Alat Kesehatan dan Bahan Medis Habis Pakai yang aman, bermutu, bermanfaat, dan terjangkau.

Seorang apotiker tidak diijinkan mengganti obat generik dengan obat paten, dan apotiker wajib berkonsultasi kepada dokter apabila pasien tidak mampu untuk membeli obat yang tercantum dalam resep, dan apoteker wajib memberikan informasi : Yang berkaitan dengan penggunaan obat yang diserahkan kepada pasien. Pengguna an obat secara tepat, aman, rasional, atas permintaan masyarakat.

Sesuai ketentuan permenkes nomor 9 tahun 2017 Hal ini karena ketentuan yang lama ada beberapa hal yang sering diabaikan oleh pengusaha apotek diantara nya mengenai pemberian informasi tentang obat-obatan dengan resep dokter. Pengusaha apotek hanya menyerahkan obatnya dalam wadah hanya tertulis nama pasien atau aturan pakai, sedangkan konsumen tidak mengetahui manfaat secara rinci obat yang mereka minum. Informasi pada konsumen akan menggugah minat menaikkan kenhendak konsumen untuk berpartisipasi aktif dalam cara pengobatan yang dapat dinilai sebagai mempercepat kesembuhannya. Pemberian iformasi yang benar sangat diperlukan bagi konsumen.

Dalam undang-undang Nomor 8 tahun 1999 tentang perlindungan konsumen. Pasal 4 menyatakan bahwa 
konsumen mempunyai hak antara lain adalah:

a. Hak atas kenyamanan, keamanan, dan keselamatan dalam mengkonsumsi barang dan/atau jasa.

b. Hak atas informasi yang benar, jelas dan jujur mengenai kondisi dan jaminan barang atau jasa.

c. Hak untuk mendapatkan konpensasi, ganti rugi dan/atau pengatian apabila barang dan atu jasa yang diterima tidak sesuai dengan perjajian atau tidak sebagai mestinya.

Pada kenyataannya masih banyak terjadi kasus yaitu tentang salah memberi kan obat oleh pihak apotek kepada konsumen. Perumusan masalah penelitian ini adalah :

1. Bagaimanakah tanggung jawab pengusaha / pengelola apotek terhadap konsumen dalam menyediakan obatobatan?

2. Masalah apa sajakah yang dihadapai pengusaha/pengelola apotek dalam melakukan kewajibannya?

\section{PEMBAHASAN}

\section{Tanggung Jawab Pengusaha / Pengelola Apotek Terhadap Konsumen Dalam Menyediakan Obat-Obatan}

Tanggung Jawab pelayanan obatobatan di apotek berpedoman pada Peraturan Menteri Kesehatan Republik Indonesia Nomer 9 Tahun 2017 Tentang Apotik bahwa : Penyelenggaraan Pasal 16 Apotek menyelenggarakan fungsi: a. pengelolaan Sediaan Farmasi, Alat Kesehatan, dan Bahan Medis Habis Pakai; dan b. pelayanan farmasi klinik, termasuk dikomunitas.

Pasal 17 (1) Apotek hanya dapat menyerahkan Sediaan Farmasi, Alat Kesehatan, dan Bahan Medis Habis Pakai kepada : a.Apotek lainnya; b.Puskesmas; c. Instalasi Farmasi Rumah Sakit; d. Instalasi
Farmasi Klinik; e. dokter; f. bidan praktik mandiri; g. pasien; dan h.masyarakat. (2) Penyerahan Sediaan Farmasi, Alat Kesehatan, dan Bahan Medis Habis Pakai sebagaimana dimaksud pada ayat (1) huruf a sampai dengan huruf $d$ hanya dapat dilakukan untuk memenuhi kekurangan jumlah sediaan farmasi, alat kesehatan, dan bahan medis habis pakai dalam hal: a. terjadi kelangkaan Sediaan Farmasi, Alat Kesehatan, dan Bahan Medis Habis Pakai di fasilitas distribusi; dan b. terjadi kekosongan Sediaan Farmasi, Alat Kesehatan, dan Bahan Medis Habis Pakai di fasilitas pelayanan kesehatan. (3) Penyerahan sediaan farmasi, alat kesehatan, dan bahan medis habis pakai sebagaimana dimaksud pada ayat (1) huruf e sampai dengan huruf $h$ hanya dapat dilakukan sesuai dengan ketentuan peraturan perundang-undangan. yo. Permenkes Nomor 26/Men.Kes/I/1981 tentang pengelolaan apotek. Pada pasal 2, pasal 3 dan pasal 4 peraturan tersebut menyebutkan sebagai berikut:

Pasal 2:

Pengelolaan Apotek meliputi;

a. Bidang Pelayanan Kefarmasian

b. Bidang material

c. Bidang administrasi dan keuangan

d. Bidang ketenagaan

e. Bidang-bidang lainnya yang berkaitan dengan tugas dan fungsi apotek

Pasal 3:

Pengelolaan apotek di bidang pelayanan kefarmasian meliputi:

a. Pembuatan, pengelolaan, peracikan, penggunaan bahan baku campuran, penyimpanan dan penyerahan obat dan bahan obat.

b. Pengadaan, penyimpanan, penyaluran serta penyerahan perbekalan kesehatan di bidang farmasi lainnya.

c. Informasi mengenai perbekalan kesehatan di bidang farmasi.

Pasal 4:

Pengelolaan informasi yang dimaksud dalam pasal 3 huruf c meliputi: 
a. Pengelolaan informasi tentang obat dan perbekalan farmasi lainnya yang diberikan baik kepada konsumen. Apabila dengan resep dokter hanya berkisar pada penggunaan obat secara benar. Sedangkan jika tanpa resep mengenai khasiat obat maupun penggunaannya dan akibatnya apabila aturan pemakaiannya tidak ditaati.

b. Pengamatan dan pelaporan informasi mengenai khasiat, keamanan, bahaya dan atau mutu obat dan perbekalan farmasi lainnya.

c. Informasi yang dimaksud pada huruf a pasal ini

Disamping berpedoman pada peraturan menteri kesehatan republik indonesia, apotek juga berusaha atau berupaya agar dapat memuaskan konsumen baik konsumen. Untuk itu, maka setiap pegawai apotek harus mempunyai jiwa salesmanship dan sosial yang tinggi.

Secara garis besar pelaksanaan penyaluran obat tidak berdasarkan pada suatu peraturan yang bersifat umum, tetapi berdasarkan pada peraturan khusus yang ditetapkan oleh departemen Kesehatan Republik Indonesia. Depertemen ini secara langsung membawahi dan mengawasi penyaluran obat melalui apotek di seluruh indonesia.

Ketentuan dan tata cara pengelolaan apotek hanya diperbolehkan melaksanakan pengadaan, penyimpanan dan penyaluran obat dan perbekalan kesehatan di bidang farmasi lainnya yang:

a. Telah memenuhi ketentuan peraturan perundang-undangan yang berlaku, misalnya Keputusan Menteri Kesehatan Republik Indonesia Nomor 1332/Menkes/SK/X/2002 Tentang Perubahan atas Peraturan Menteri Kesehatan RI No. 922/Menkes/Per/X/ 1993 Tentang Ketentuan dan Tata Cara Pemberian Izin Apotek maupun yo ketentuan permenkes nomor 9 tahun 2017 tentang apotek bersumber dari pabrik farmasi, pedagang besar farmasi, apotek lain atau sarana distribusi lain yang sah.

Obat-obatan yang diedarkan oleh apotek dibagi menurut tingkat keamanan nya menjadi beberapa kelompok. Kelompok ini selanjutnya menentukan mudah sukarnya obat didapatkan di pasaran. Obat relatif aman (relatif kurang beracun) akan lebih mudah didapat daripada obat yang kurang aman (relatif beracun). Makin kurang aman atau makin berbahanya suatu obat, makin ketat obat itu diawasi peredarannya dan pemakaiannya oleh pemerintah. Sehingga untuk mendapatkannya obat-obatan tersebut harus dengan resep dokter dan hanya dapat dibeli di apotek.

Kelompok obat yang berdasarkan dari segi keamanannya, antara lain :

a. Kelompok Obat Biasa

Sesuai dengan namanya, obat-obatan dalam golongan tersebut di atas dapat diperjualbelikan dengan bebas tanpa resep dokter dan dapat dibeli di apotek. Sebagai tanda obat bebas, pada pembungkusnya diberi tanda khusus, warna hijau di dalam lingkaran hitam. Termasuk obat kelompok ini adalah : Vitamin B Compleks, Vitamin B1, Tablet Vitamin A, Vitamin C, Multi vitamin dan sebagainya.

Golongan obat bebas ini biasanya tidak membahayakan jiwa, dalam arti kata yang agak luas bila makan jumlah 10-20 biji sekaligus belum tentu sampai mati saat itujuga.

b. Kelompok Obat Bebas Terbatas

Pada zaman belanda, kelompok obat ini juga disebut obat daftar W (W= waarschuing - peringatan). Obat-obatan yang termasuk dalam kelompok ini dapat dijual belikan secara bebas dengan syarat hanya dalam jumlah yang telah ditentukan dan disertai dengan tanda peringatan.Tanda peringatan ditulis dengan huruf putih di atas kertas yang pada umumnya berwama hitam. Tanda lain untuk obat bebas terbatas ini, 
pada pembungkusnya diberi tanda khusus, warna biru di dalam lingkaran warna hitam.

Yang termasuk dalam kelompok ini adalah tablet antimo, merkurokorm, Vitamin E (maksimal $120 \mathrm{mg}$ ), kreosal dan lain-lain.

c. Kelompok Obat Keras

Obat-obat golongan golongan ini sangat berbahaya, mempunyai efek samping yang sangat besar dan untuk mendapatkannya diperlukan resep dokter yang hanya dibeli di apotek. Pada pemakaian yang tidak hati-hati dapat mengakibatkan hal-hal yang tidak diinginkan dan dapat mengakibatkan maut, misalnya menimbulkan gangguan metabolisme, gangguan saluran kencing, mengakibatkan penyakit kurangnya pembentukan bentuk darah tertentu (agranulocytosis). Lebih dari 100 bahan obat termasuk kelompok ini, meliputi antibiotika, obat-obatan yang tercantum dalam daftar obat bebas terbatas, bila jumlahnya melebihi dari pada yang ditentukan oleh daftar itu, obat- obatan yang berpengaruh pada susunan saraf seperti penenang, obat-obat yang digunakan dengan cara penyuntikan dan masih banyak lagi lainnya.

Sebagai tanda obat keras, pada pembungkusnya diberi tanda khusus, huruf $\mathrm{K}$ dengan latar belakang wama merah di dalam lingkaran wama hitam.

d. Kelompok Narkotika

Obat ini seperti halnya dengan obat daftar $G$, hanya dapat diperoleh di apotek dengan resep dokter.Dalam dunia kefarmasian terkenal dengan obat golongan $\mathrm{O}$ (Opium).Berbeda dengan obat keras, peredaran obat narkotika ini sangat ketat dan diawasi oleh Badan Pengawas Obat.Di apotek keluar masuknya obat narkotika ini mempunyai akibat buruk, tidak hanya pada badan pemakainya, tetapi termasuk masyarakat sekelilingnya.
Hal ini disebabkan karena mengakibat kan kecanduan, ketergantungan pada obat tersebut dan dapat merusak kepribadian pemakainya. Jadi masalah narkotika ini bukan hanya merupakan masalah medis tetapi juga masalah sosial. Contoh obat narkotika adalah morfina, kokaina, petidia dan lain sebagainya.

Sebuah peraturan lain untuk melindungi konsumen obat adalah keharusan untuk disertakan brosur itu tercantum hal-hal yang perlu diketahui sebelum pemakai obat meminumnya, seperti dosis, aturan pakai, waktu pemakaian, indikasi (penyakit yang akan diobati oleh obat tersebut), kontra indikasi (keadaan-keadaan pemakai dimana tidak diijinkan memakai obat tersebut), efek keija sampingan yang mungkin timbul dan lain sebagainya. Sayang terkadang konsumen masih sering mengabaikan brosur tersebut dan tidak membacanya lebih dahulu sebelum memakai atau meminum obat tersebut bahkan sering dibuang begitu saja.Ini merupakan suatu hal yang patut disayangkan. Sebagai tanda narkotika, pada pembungkusnya diberi tanda khusus, palang merah dengan latar belakang putih, di dalam lingkaran warnsa merah.

Terhadap kelompok obat nomor 3 dan 4 di atas (obat keras dan narkotika), apotek juga bertanggungjawab terhadap penerimaan resep dari konsumen sesuai dengan tugas dan fungsi apotek, yaitu :

1) Melaksanakan pembuatan, pengolahan, peracikan, pengubahan bentuk campuran, penyimpanan, penyaluran dan penyerahan obat.

2) Melaksanakan pengadaan, penyimpan an, penyaluran dan penyerahan perbekalan kesehatan di bidang farmasi.

3) Apotek dapat melakukan pembuatan, pengubahan bentuk, pencampuran, peracikan obat dan bahan obat untuk pelayanan resep dokter gigi dan dokter hewan. 
4) Apotek dapat melakukan pembuatan, pengubahan bentuk, pencampuran, peracikan obat untuk pelayanan langsung tanpa resep khusus untuk obat bebas dan obat bebas terbatas.

5) Apotek dapat melakukan pembuatan, pengubahan bentuk, pencampuran, peracikan obat dan bahan obat untuk pelayanan lain sesuai dengan ketentuan perundang-undangan yang berlaku.

Apabila terjadi kasus obat yang tertulis dalam resep sudah tidak beredar lagi, tindakan dari apotek adalah : Apoteker dan asisten apoteker harus memberitahukan secara lisan (melalui telepon) atau secara tertulis kepada dokter yang menulis resep tersebut dan memberitahukan kepada konsumen bahwa obat yang diminta atau ditulis dalam resep sudah tidak beredar lagi.

Apabila pasien belum mengerti dan tidak percaya obat tersebut sudah tidak beredar lagi, maka tindakan dari apotek adalah : Apoteker dan asisten apoteker harus memberitahukan secara lisan (melalui telepon) atau secara tertulis kepada dokter yang menulis resep tersebut dan memberitahukan kepada konsumen bahwa obat yang diminta atau ditulis dalam resep sudah tidak beredar lagi.

Apabila konsumen belum mengerti dan tidak percaya bahwa obat tersebut sudah tidak beredar lagi, maka ditunjukkan surat pernyataan bahwa obat tersebut sudah dicabut dari peredarannya dan dikeluarkan oleh Kantor Wilayah Kesehatan Republik Indonesia.

Tugas apotek adalah menyalurkan obat-obatan (bebas dan dengan resep). Untuk pelaksanaannya di lapangan menyalurkan obat-obatan tersebut antara lain:

a. Terhadap obat bebas

Obat bebas merupakan obat yang tidak digolongkan sebagai obat keras, obat psikotropika maupun narkotik. Sehingga untuk mendapatkannya konsumen dapat secara langsung dan tidak perlu menggunakan resep dokter.
Walaupun dalam obat bebas telah tercantum mengenai aturan pemakaian nya tidak menutup kemungkinan pihak apotek untuk memberikan informasi untuk cara pemakaian, dosis obat maupun efek samping atau resiko yang mungkin timbul. Konsumen juga harus sadar tentang kemungkinan terjadinya interaksi antara obat bebas dengan obat yang ditulis dalam resep yang diminum.Bila dalam menggunakan obat tanpa resep oleh konsumen tidak segera meringankan keluhan secara cepat, pengelola apotek haras menasehati konsumen untuk segera periksa pada dokter.

b. Terhadap obat dengan resep

Berdasarkan Permenkes nomor 9 tahun 2017 tentang Apotek mnyatakan bahwa: Setiap Apoteker dan Tenaga Teknis Kefarmasian harus bekerja sesuai dengan standar profesi, standar prosedur operasional, standar pelayanan, etika profesi, menghormati hak pasien dan mengutamakan kepentingan pasien. termasuk disini pelayanan obat dengan menggunakan resep.

Dalam Pasal 21

1) Apoteker wajib melayani Resep sesuai dengan tanggung jawab dan keahlian profesinya yang dilandasi pada kepentingan masyarakat.

2) Dalam hal obat yang diresepkan terdapat obat merek dagang, maka Apoteker dapat mengganti obat merek dagang dengan obat generik yang sama komponen aktifnya atau obat merek dagang lain atas persetujuan dokter dan/atau pasien.

3) Dalam hal obat yang diresepkan tidak tersedia di Apotek atau pasien tidak mampu menebus obat yang tertulis di dalam Resep, Apoteker dapat mengganti obat setelah berkonsultasi dengan dokter penulis Resep untuk pemilihan obat lain.

4) Apabila Apoteker menganggap 
penulisan Resep terdapat kekeliruan atau tidak tepat, Apoteker harus memberitahukan kepada dokter penulis Resep.

5) Apabila dokter penulis Resep sebagaimana dimaksud pada ayat (4) tetap pada pendiriannya, maka Apoteker tetap memberikan pelayanan sesuai dengan Resep dengan memberikan catatan dalam Resep bahwa dokter sesuai dengan pendiriannya.

Pasal 22

1) Pasien berhak meminta salinan Resep.

2) Salinan Resep sebagaimana dimaksud pada ayat (1) harus disahkan oleh Apoteker. (3) Salinan Resep sebagaimana dimaksud pada ayat (1) harus sesuai aslinya sesuai dengan ketentuan peraturan perundangundangan.

Pasal 23

1) Resep bersifat rahasia.

2) Resep harus disimpan di Apotek dengan baik paling singkat 5 (lima) tahun.

3) Resep atau salinan Resep hanya dapat diperlihatkan kepada dokter penulis Resep, pasien yang bersangkutan atau yang merawat pasien, petugas kesehatan atau petugas lain yang berwenang sesuai dengan ketentuan peraturan perundang-undangan.

Yang termasuk obat dengan menggunakan resep dokter adalah obat bebas terbatas dan obat keras serta narkotika. Dalam melayani pembelian obat dengan resep ini, pihak apotek haras memeriksa terlebih dahulu mengenai syarat-syarat resep seperti yang tercantum dalam Pasal 2 Keputusan Menteri Kesehatan Republik

Hubungan hukum antara Apoteker dengan pasien berdasarkanUndangUndang Nomor 8 Tahun 1999 Tentang Perlindungan Konsumen, (UUPK) yaitu apoteker dapat bertindak sebagai pelaku usaha dan pasien bertindak sebagai konsumen obat, yakni pemakai jasa layanan kesehatan. Prinsip tentang tanggung jawab merupakan perihal yang sangat penting dalam hukum perlindungan konsumen. Dalam kasus-kasus pelanggaran hak konsumen, diperlukan kehati-hatian dalam menganalisis siapa yang harus bertanggung jawab dan seberapa jauh tanggung jawab yang dapat dibebankan kepada pihak-pihak terkait. Dalam rangka memberikan perlindungan konsumen maka sesuai dengan Undang-undang nomor 8 tahun 1999, tentang perlindungan konsumen dalam hal ini konsumen obat tanggung jawab pengusaha apotek adalah:

a. Pengusaha apotek bertanggung jawab memberikan ganti rugi atas kerusakan dan/atau kerugian konsumen akibat mengkonsumsi barang dan/atau jasa yang dihasilkan atau diperdagangkan.

b. Ganti rugi sebagaimana dimaksud pada ayat (1) dapat berupa pengembalian uang atau pengembalian barang dan/atau jasa yang sejenis atau setara nilainya, atau perawatan kesehatan dan/atau pemberian santunan yang sesuai dengan ketentuan peraturan perundang-undangan yang berlaku.

c. Pemberian ganti rugi dilaksanakan dalam tenggang waktu 7 (tujuh) setelah tanggal transaksi.

d. Pemberian ganti rugi sebagaimana dimaksud pada ayat (1) dan ayat (2) tidak menghapuskan kemungkinan adanya tuntutan pidana berdasarkan pembuktian lebih lanjut mengenai adanya unsur kesalahan.

e. Ketentuan sebagaimana dimaksud pada ayat (1) dan ayat (2) tidak berlaku apabila pelaku usaha dapat membuktikan bahwa kesalahan tersebut merupakan kesalahan konsumen.

Bahwa tanggung jawab Pengelola apotek dalam menyediakan obat-obatan bagi masyarakat (konsumen) adalah sebagai berikut:

a. Menyediakan obat-obatan dan alat kesehatan yang dibutuhkan oleh konsumen termasuk KB. 
b. Menyalurkan dan menyediakan obat yang dibutuhkan oleh golongan konsumen yang berpenghasilan rendah.

c. Menyelenggarakan upaya kesehatan seperti yang diatur oleh pemerintah dan dilakukan secara serasi dan seimbang antara masyarakat dan pemerintah.

d. Menyelenggarakan upaya peningkatan kesehatan dan pencegahan penyakit yang dilakukan secara terpadu dengan upaya penyembuhan dan pemulihan, misalnya dengan menyediakan obat generik yang harganya cukup teijangkau oleh masyarakat.

e. Merangsang pembangunan kesehatan yang berlandaskan pada kepercayaan akan kemampuan dan kekuatan sendiri yang bersendikan kepribadian bangsa.

f. Membantu konsumen dalam rangka menjunjung tinggi dan mentaati segala ketentuan peraturan perundangundangan dalam bidang kesehatan.

g. Memenuhi kebutuhan dan menyedia kan alat-alat kesehatan untuk me laksanakan pembangunan kesehatan yang dapat dinikmati secara merata oleh seluruh konsumen.

h. Memanfaatkan potensi yang ada guna diarahkan untuk pembangunan di bidang kesehatan.

i. Merangsang sikap gotong royong dan kekeluargaan guna mencapai pem bangunan kesehatan di segala bidang.

Berdasarkan ketentuan di dalam pasal 29 Undang-Undang Kesehatan Nomor 36 Tahun 2009 berbunyi "Dalam hal tenaga kesehatan diduga melakukan kelalaian dalam menjalankan profesinya kelalaian tersebut harus diselesaikan terlebih dahulu melalui mediasi". Apabila mengalami suatu kerugian yang ditimbulkan akibat wanprestasi dapat meminta pertanggung jawaban kepada apotek melalui apoteker. karena Wanprestasi adalah berarti ketiadaan suatu prestasi dalam hukum perjanjian, berarti suatu hal harus dilaksanakan sebagai isi suatu perjajian.
Apabila terjadi kesalahan atau pelanggaran yang dilakukan oleh apotek maka konsumen dapat mengajukan gugatan ganti kerugian atau dapat melaporkan kepada yang berwajib. Ganti kerugian tersebut bisa dilakukan dengan pemberian penggantian obat dan ganti kerugian berupa uang apabila mengalami kerugian yang dialami atau akibat dari minum obat yang diberikan pihak apotek.

Dalam hal Apotek melakukan pelanggaran berat yang membahayakan jiwa, berdasarkan Peraturan Menteri Kesehatan Nomer 9 Tahun 2017 Tentang Apotek, maka sanksinya SIA dapat dicabut tanpa peringatan terlebih dahulu. Keputusan Pencabutan SIA oleh pemerintah daerah kabupaten/kota disampaikan langsung kepada Apoteker dengan tembusan kepada Direktur Jenderal, kepala dinas kesehatan provinsi, dan Kepala Badan

\section{Masalah yang Dihadapi Pengusaha Apotek Dalam Melakukan Kegiatan Usahanya.}

Dalam melaksanakan kegiatannya untuk memberikan pelayanan kepada konsumen tidak semudah yang dibayang kan. Masih terdapat masalah yang harus dihadapi oleh pengusaha apotek demi tercapainya pelayanan yang baik bagi konsumen.

Masalah yang dihadapi oleh pengusaha atau pengelola apotek dalam melaksanakan tugasnya antara lain :

a. Obat yang sudah tidak beredar lagi

Apabila apotek menerima resep yang ditulis dokter dan ternyata obat yang ditulis dalam resep itu sudah tidak beredar lagi dan hal ini masih sering terjadi yang mungkin disebabkan oleh kurangnya informasi dari pihak produsen obat maupun dari PBF kepada para dokter.Untuk mengatasi masalah ini pihak apotek menanyakan pihak dokter yang menulis resep tersebut. 
Kemudian setelah pihak apotek menerima penjelasan/saran dari dokter yang menulis resep itu, maka pihak apotek memberikan obat sebagaimana saran dokter sebagai penggantinya yang sesuai dengan kegunaannya. Jika dokter yang menulis resep tersebut sulit ditemuiatau dihubungi maka harus mengambil keputusan untuk mengambil obat yang ditulis dengan obat lain yang mempunyai dosis dan kegunaan yang sama sehingga yang membutuhkan obat akan segera tertolong tanpa harus menunggu terlalu lama. Jika pemberian obatpengganti atas saran pihak apotek, maka apabila ada efek sampingnya menjadi tanggung jawab pihak apotek.

b. Obat yang sudah kadaluarsa

Masalah lain yang dihadapi dalam penukaran obat-obatan yang sudah kadaluarsa ED (Expired), penukaran pada PBF (Pedagang Besar Farmasi) memakan waktu yang lama kadang sampai lebih dari satu bulan sehingga mengganggu stok barang apotek.

Untuk mengatasi masalah tersebut, maka yang dilakukan pengusaha apotek adalah tiga bulan sebelum kadaluarsa obat-obatan tersebut sudah dikembali kan ke PBF untuk ditukar dengan obat yang sejenis atau obat merk lain yang dibutuhkan.

c. Persediaan obat habis

Apabila apotek menerima resep yang ditulis oleh dokter untuk pasien ternyata obat yang ditulis dalam resep sebagian ada yang sudah habis persediaannya, maka petugas apotek akan menyarankan konsumen mencari obat yang habis tersebut ke apotek lain yang menjual obat yang dimaksud. Tetapi pada prakteknya pihak apotek biasanya menyarankan untuk membeli produk lain yang ada di apoteknya yang mempunyai kegunaan sama.

Masalah tersebut dapat diatasi dengan baik, sehingga tidak mengecewakan pasien atau konsumen yaitu dengan menyarankan untuk mencari obat sejenis ke apotek lain yang mempunyai obat tersebut atau berkonsultasi dengan dokter yang bersangkutan.

\section{Kesimpulan}

Tanggung jawab pengusaha / pengelola apotek terhadap konsumen obat dalam menyediakan dan menyelurkan obat-obatan antara lain apabila terjadi kelalaian, kesalahan yang disebabkan oleh pihak pengelola apotek sehingga dapat merugikan konsumen obat, maka secara perdata pengelola apotek wajib bertanggung jawab dengan memberikan ganti rugi sesuai dengan kerugian yang diderita konsumen, Apabila kesalahan tersebut tidak fatal bagi konsumen, maka pihak pengelola apotek akan memberikan ganti rugi berupa pengembalian uang, atau obat yang sejenis atau yang sesuai dengan peraturan perundangundangan yang berlaku.

Berdasarkan ketentuan di dalam pasal 29 Undang-Undang Kesehatan Nomor 36 Tahun 2009 yang berbunyi "Dalam hal tenaga kesehatan diduga melakukan kelalaian dalam menjalankan profesinya kelalaian tersebut harus diselesaikan terlebih dahulu melalui mediasi". Apabila mengalami suatu kerugian yang ditimbulkan akibat wanprestasi dapat meminta pertanggung jawaban kepada apotek melalui apoteker.atau bisa dengan mengajukan gugatan ganti kerugian ke pengadilan atau dapat melaporkan kepada yang berwajib, ganti kerugian tersebut bisa dilakukan dengan pemberian penggantian obat dan ganti kerugian berupa uang apabila kerugian yang dialami akibat dampak dari minum obat yang diberikan oleh pihak apotek.

Dalam hal Apotek melakukan pelanggaran berat yang membahayakan jiwa, berdasarkan Peraturan Menteri Kesehatan Nomer 9 Tahun 2017 Tentang Apotek, maka sanksinya SIA dapat dicabut tanpa peringatan terlebih dahulu. Keputusan Pencabutan SIA oleh pemerintah daerah kabupaten/kota disampaikan langsung kepada Apoteker dengan tembusan kepada Direktur Jenderal, kepala dinas kesehatan provinsi. 


\section{DAFTAR PUSTAKA}

Ahmad Miru dan Sutarman, Hukum Perlindungan Konsumen, Raja Grafindo Persada, Jakarta, 2004

---------,Prinsip Prnsip Perlindungan Hukum Bagi Konsumen di Indonesia, Program Pascasarjana Unair Surabaya.

Gunawan Wijaya dan Ahmad Yani, Hukum

Tentang Perlindungan Konsumen, Gramedia Pustaka Utama, Jakarta, 2003.

Moh Anief, Apa Yang Perlu Diketahui Tentang Obat, Gajahmada University Press, yogyakarta,1997.

IShidarta, Hukum Perlindungan Konsumen Indonesia, Grasindo Jakarta, 2000.

SriRedjeki Hartono, Aspek aspek Hukum PerlindnganKonsumen Dalam Kerangka Era Perdagangan Bebas, Manda Maju, Bandung, 2000.

Sudaryato, Hukum dan Advokasi Konsumen, Citra Aditya Bhakti, Bandung, 1999
Velden, Ekonomi Pembangunan, Bina Aksara Jakarta, 1995

Yusuf Shofie, Perlindungan Konsumen dan Instrumen Hukumnya, Citra Aditya Bhakti, Bandung, 2003.

Yustina Sri Hartini dan Sulasmono, Apotek, Universitas Sanata Dharma. Yogyakarta, 2008.

Undang-Undang Nomor 23 tahun 1992 Tentang Kesehatan jo UndangUndang Nomor 36 Tahun 2009 Tentang Kesehatan.

Undang-Undang Nomor 8 Tahun 1999 Tentang Perlindungan Konsumen (UUPK).

Peraturan Menteri Kesehatan Republik Indonesia Nomor 35 Tahun 2014 tentang Standar Pelayanan Kefarmasian

Peraturan Pemerintah Nomor 51 Tahun 2009 Tentang Pekerjaan Kefarmasian.

Keputusan Menteri Kesehatan Nomor 347/ MenKes/SK/VII/1990 Tentang Obat Wajib Apotek ${ }^{1}$ 